Tri Kurniastuti, Palupi Puspitorini, Tyas Nyonita Punjungsari, 2017. Pengaruh Penambahan Abu sekam Padi (Rice Husk Ash) dengan Proporsi Berbeda Terhadap Pertumbuhan Selada Air (Lactuca sativa L.). Journal Viabel Pertanian. (2017),11(2) 1-8

\title{
PENGARUH PENAMBAHAN ABU SEKAM PADI (RICE HUSK ASH) DENGAN PROPORSI YANG BERBEDA TERHADAP PERTUMBUHAN SELADAI AIR (Lactuca sativa L.)
}

\author{
Tri Kurniastuti ${ }^{1)}$ \\ Palupi Puspitorini ${ }^{2)}$ \\ Tyas Nyonita Punjungsari ${ }^{3)}$
}

1) Dosen prodi Agroteknologi, Fakultas Pertanian, Universitas Islam Balitar

2) Dosen prodi Agroteknologi, Fakultas Pertanian, Universitas Islam Balitar

3) Dosen prodi Agroteknologi, Fakultas Pertanian, Universitas Islam Balitar

\begin{abstract}
ABSTRAK
Lettuce vegetables (Lactuca sativa L.) much needed by the community to meet the nutritional needs, but lettuce production is still low because of low productivity. Increasing the quality and quantity of vegetables grown on polybags is by fertilizing and arranging the composition of the planting medium. Provision of fertilizer aims to increase the supply of nutrients needed plants to boost the production and quality of crops. Fertilizer is to provide or add nutrients that plants need. However, fertilizer will tend to cause high production value and less appropriate with vegetable planting at home, therefore more optimized setting the composition of planting media. Planting media should be able to provide nutrients needed by plants. Farmers use plant residual organic materials such as rice husk as and cockpit for vegetable cultivation. The rice husk is the outermost part of the grain. The rice husk ash usually contains $\mathrm{N} 0.32 \%, \mathrm{P} 0.15 \%, \mathrm{~K} 0.31 \%, \mathrm{Ca} 0.96 \%, \mathrm{Fe}$ $180 \mathrm{ppm}, \mathrm{Mn} 80.4 \mathrm{ppm} \mathrm{Zn} 14.10 \mathrm{ppm}$ and $\mathrm{pH}$ 6, 8 which is expected to meet the needs of plant nutrients. The study was prepared using a complete randomized design with one factor that is the addition of planting media in the form of rice husk ash with the proportion of top soil and rice husk ash as follows: M1 (3:1), M2 (2:2), and M3 (1:3). The observed variables were stem height, crown dry weight, and root dry weight. Data analysis used $F$ Test 5\% and continued with Duncan Multiple Range Test (DMRT) 5\%. The results obtained at plant height of M3 (1:3) gave the best result where there was a plant height increase of $40 \mathrm{~cm}$ from the first day of planting until the third day, the addition of rice husk ash did not affect the addition of root dry weight and dry weight of crown.
\end{abstract}

Keywords: Rice Husk Ash, Proportion, Lettuce Growth.

\section{PENDAHULUAN}

Tanaman selada (Lactuva sativa L) sudah lama dikenal dan dibudidayakan oleh masyarakat Indonesia karena tanaman selada ini merupakan salah satu sayuran yang mempunyai nilai komersial dan prospek yang cukup baik untuk dikembangkan. Permintaan terhadap tanaman selada ini terus meningkat seiring dengan meningkatkannya jumlah penduduk di Indonesia dan kesadaran masyarakat akan pentingnya gizi yang berimbang. Namun peningkatan permintaan bertolak 
Tri Kurniastuti, Palupi Puspitorini, Tyas Nyonita Punjungsari, 2017. Pengaruh Penambahan Abu sekam Padi (Rice Husk Ash) dengan Proporsi Berbeda Terhadap Pertumbuhan Selada Air (Lactuca sativa L.). Journal Viabel Pertanian. (2017),11(2) 1-8

belakang dengan semakin sempitnya lahan pertanian, karena saat ini sebagian lahan pertanian beralih fungsi menjadi perumahan dan industri. Penanaman tanaman sayuran pada polybag merupakan salah satu alternative agar kuantitas produk selada terpenuhi minimal di tingkat rumah tangga, lokal dan regional.

Salah satu teknik budidaya yang dapat diterapkan untuk meningkatkan kualitas dan kuantitas sayuran yang ditanam pada polibag adalah dengan pemupukan dan pengaturan komposisi media tanam. Pemberian pupuk bertujuan menambah persediaan unsur-unsur hara yang dibutuhkan tanaman untuk menigkatkan produksi dan mutu hasil tanaman. Pupuk adalah menyediakan atau menambah unsur hara yang dibutuhkan tanaman [12]. Namun pemberian pupuk akan cenderung menyebabkan nilai produksi yang tinggi dan kurang sesuai dengan penanaman sayur sekala rumahan, oleh karenanya lebih dioptimalkannya pengaturan komposisi media tanamnya. Media tanam seharusnya mampu menyediakan unsur - unsur hara yang dibutuhkan oleh Tanaman.

Umumnya petani menggunakan bahan organik sisa tanaman seperti sekam padi dan kokopit untuk budidaya tanaman sayuran. Sekam padi adalah bagian terluar dari butir padi. Sekam padi merupakan produk samping yang melimpah dalam proses penggilingan padi, yaitu sekitar $20 \%$ dari bobot gabah. Sekam padi terdiri dari senyawa organik dan senyawa anorganik. Komposisi senyawa organik dalam sekam padi terdiri atas protein, lemak, serat, pentosa, selulosa, hemiselulosa, dan lignin. Sedangkan komposisi senyawa anorganik biasanya terdapat dalam abunya.

Menurut (Houston, 1972) komposisi arang sekam paling banyak mengandung senyawa $\mathrm{SiO}_{z}$ sebanyak $52 \%$ dan unsur C sebanyak $31 \%$. Komposisi lainnya adalah $\mathrm{Fe}_{2} \mathrm{O}_{3}, \mathrm{~K}_{2} \mathrm{O}, \mathrm{MgO}, \mathrm{CaO}, \mathrm{MnO}$ dan $\mathrm{Cu}$ dalam jumlah yang sangat kecil, juga mengandung bahan-bahan organik. Sedangkan menurut analisis Suyekti (1993) sekam bakar mengandung N 0,32 \%, P 0,15\%, K 0,31 \%, Ca 0,96\%, Fe 180 ppm, Mn 80,4 ppm Zn 14,10 ppm dan pH 6,8. Soepardi (1983) mengemukakan bahwa kadar kalium dalam abu sekam lebih kurang sama dengan $30 \% \mathrm{~K}_{2} \mathrm{O}$. Karakteristik lain arang sekam adalah sangat ringan (Berat Jenis $=0,2 \mathrm{~kg} / \mathrm{l}$ ), kasar sehingga sirkulasi udara tinggi (banyak pori), kapasitas menahan air tinggi, berwarna coklat kehitaman sehingga dapat mengabsorbsi sinar matahari dengan efektif serta dapat mengurangi pengaruh penyakit khususnya bakteri (Douglas, 1985). Agustin et al, (2014) menyampaikan bahawa Karakteristik arang sekam padi adalah memiliki sifat lebih remah dibanding media tanam lainnya.

Berdasarkan pertimbangan tersebut, penulis bermaksud mengadakan penelitian dengan judul "Pengaruh Penambahan Abu Sekam Padi (Riece Husk As) Dengan Proporsi yang Berbeda Terhadap Pertumbuhan Selada Air (Lactuca sativa L)". 
Tri Kurniastuti, Palupi Puspitorini, Tyas Nyonita Punjungsari, 2017. Pengaruh Penambahan Abu sekam Padi (Rice Husk Ash) dengan Proporsi Berbeda Terhadap Pertumbuhan Selada Air (Lactuca sativa L.). Journal Viabel Pertanian. (2017),11(2) 1-8

\section{TINJAUAN PUSTAKA}

\section{Sekam padi}

Sekam padi adalah bagian terluar dari butir padi. Sekam padi merupakan produk samping yang melimpah dalam proses penggilingan padi, yaitu sekitar $20 \%$ dari bobot gabah. Sekam padi terdiri dari senyawa organik dan senyawa anorganik. Komposisi senyawa organik dalam sekam padi terdiri atas protein, lemak, serat, pentosa, selulosa, hemiselulosa, dan lignin. Sedangkan komposisi senyawa anorganik biasanya terdapat dalam abunya.

Menurut (Houston, 1972) komposisi arang sekam paling banyak mengandung senyawa $\mathrm{SiO}_{z}$ sebanyak $52 \%$ dan unsur C sebanyak $31 \%$. Komposisi lainnya adalah $\mathrm{Fe}_{2} \mathrm{O}_{3}, \mathrm{~K}_{2} \mathrm{O}, \mathrm{MgO}, \mathrm{CaO}, \mathrm{MnO}$ dan $\mathrm{Cu}$ dalam jumlah yang sangat kecil, juga mengandung bahan-bahan organik. Sedangkan menurut analisis Suyekti (1993) sekam bakar mengandung N 0,32 \%, P 0,15\%, K 0,31\%, Ca 0,96 \%, Fe 180 ppm, Mn 80,4 ppm Zn 14,10 ppm dan pH 6,8. Soepardi (1983) mengemukakan bahwa kadar kalium dalam abu sekam lebih kurang sama dengan $30 \% \mathrm{~K}_{2} \mathrm{O}$.

\section{Selada air}

Selada (Lactuca sativa $L$ ) adalah tanaman yang termasuk dalam famili Compositae (Sunarjono, 2014). Sebagian besar selada dimakan dalam keadaan mentah. Selada merupakan sayuran yang populer karena memiliki warna, tekstur, serta aroma yang menyegarkan tampilan makanan. Tanaman ini merupakan tanaman setahun yang dapat di budidayakan di daerah lembab, dingin, dataran rendah maupun dataran tinggi. Pada dataran tinggi yang beriklim lembab produktivitas selada cukup baik. Di daerah pegunungan tanaman selada dapat membentuk bulatan krop yang besar sedangkan pada daerah dataran rendah, daun selada berbentuk krop kecil dan berbunga (Rubatzky dan Yamaguchi, 1998).

Suhu ideal untuk produksi selada berkualitas tinggi adalah $15-25^{\circ} \mathrm{C}$. Suhu yang lebih tinggi dari $30^{\circ} \mathrm{C}$ dapat menghambat pertumbuhan, merangsang tumbuhnya tangkai bunga (bolting), dan dapat menyebabkan rasa pahit. Sedangkan untuk tipe selada kepala suhu yang tinggi dapat menyebabkan bentuk kepala longgar. Selada tipe daun longgar umumnya beradaptasi lebih baik terhadap kisaran suhu yang lebih tinggi ketimbang tipe bentuk kepala (Rubatzky dan Yamaguchi, 1998).

Selada dapat tumbuh di daerah dataran rendah maupun dataran tinggi (pegunungan). Pada daerah pegunungan, daun dapat membentuk krop yang besar sedangkan didataran rendah daun dapat membentuk krop yang kecil, tetapi cepat berbunga. Syarat penting agar selada dapat tumbuh dengan baik yaitu memiliki derajat keasaman tanah pH 5-6.5 ( Sunarjono, 2014). Selada dapat tumbuh pada jenis tanah lempung berdebu, berpasir dan tanah yang masih mengandung humus. Meskipun demikian, selada masih toleran terhadap tanah-tanah yang miskin hara 
Tri Kurniastuti, Palupi Puspitorini, Tyas Nyonita Punjungsari, 2017. Pengaruh Penambahan Abu sekam Padi (Rice Husk Ash) dengan Proporsi Berbeda Terhadap Pertumbuhan Selada Air (Lactuca sativa L.). Journal Viabel Pertanian. (2017),11(2) 1-8

dan ber-pH netral. Jika tanah asam, daun selada akan menjadi berwarna kuning. Karena itu, sebaiknya dilakukan pengapuran terlebih dahulu sebelum penanaman (Nazaruddin, 2000).

Selada memiliki sistem perakaran tunggang dan serabut. Akar serabut menempel pada batang dan tumbuh menyebar ke semua arah pada kedalaman 20$50 \mathrm{~cm}$ atau lebih. Daun selada memiliki bentuk, ukuran dan warna yang beragam tergantung varietasnya. Tinggi tanaman selada daun berkisar antara 30-40 cm dan tinggi tanaman selada kepala berkisar antara 20-30 cm (Saparinto, 2013).

Umur panen selada berbeda-beda menurut kultivar dan musim, umurnya berkisar 30-85 hari setelah pindah tanam. Bobot tanaman sangat beragam, mulai dari $100 \mathrm{~g}$ sampai $400 \mathrm{~g}$. Panen yang terlalu dini memberikan hasil panen yang rendah dan panen yang terlambat dapat menurunkan kualitas. Secara umum selada yang berkualitas bagus memiliki rasa yang tidak pahit, aromanya menyegarkan, renyah, tampilan fisik menarik serta kandungan seratnya rendah (Rubatzky dan Yamaguchi, 1998).

\section{METODE PENELITIAN}

Penelitian dilaksanakan di rumah plastik di Kelurahan Kanigoro Kecamatan Kanigoro Kabupateb Blitar pada bulan Juni sampai dengan Desember 2017 di Kelurahan Kepanjenkidul, Kecamatan Kepanjenkidul Kota Blitar Jawa Timur, dengan ketinggian tempat $144 \mathrm{~m}$ di atas permukaan laut.

Bahan-bahan yang digunakan antara lain: Benih selada varietas Green Rapid); Sekam bakar; Fungisida Dithane, insektisida Lannate; Pupuk Urea dan $\mathrm{KNO}_{3}$.Alatalat yang digunakan antara lain: Polybag; Penggaris; Rol meter; Alat Tulis; Tali; Timbangan analitik; Papan nama; Pisau; Ember; Meteran; Hand sprayer; Oven; Gelas ukur; Hand Sprayer; Bambu; Peralatan lainnya yang menunjang penelitian; Plastik mulsa hitam; Kertas; Plastik bening; Sprayer kecil.

Rancangan percobaan yang diterapkan pada penelitian ini adalah rancangan acak lengkap (RAL) dengan satu factor yaitu penambahan media tanam berupa abu sekam dengan proporsi tanah atas dan abu sekam padi seperti berikut: M1 (3:1), M2 (2:2), dan M3 (1:3). Adapun variable yang diamati tinggi batang, berat kering tajuk, dan berat kering akar. Analisis data menggunaka Uji F 5\% dan dilanjutkan dengan uji Duncan Multiple Range Test (DMRT) $5 \%$.

\section{HASIL PENELITIAN DAN PEMBAHASAN}

Berdasarkan grafik pada Gambar 1, diketahui bahwa peningkatan tinggi selada yang paling cepat adalah pada konsentrasi M3 dimana terdapat kenaikan tinggi tanaman hampir $40 \mathrm{~cm}$ pada hari pertama penanaman hingga hari ke 6 penanaman. Peningkatan tinggi tanaman paling cepat pada konsentrasi penambahan sekam padi terbanyak dapat terjadi karena abu sekam padi 
Tri Kurniastuti, Palupi Puspitorini, Tyas Nyonita Punjungsari, 2017. Pengaruh Penambahan Abu sekam Padi (Rice Husk Ash) dengan Proporsi Berbeda Terhadap Pertumbuhan Selada Air (Lactuca sativa L.). Journal Viabel Pertanian.

mengandung $\mathrm{N}$ sebesar $0,32 \%, \mathrm{P}(0,15 \%)$, K sebesar $0,31 \%$ dan $\mathrm{Ca} 0,96$ $\%$ (Suyekti, 1993). N,P,K dan Ca termasuk dalam makro element atau elemen yang dibutuhkan tanaman dalam jumlah yang cukup besar, sehingga semakin banyak proporsi abu sekam maka kecukupan makro element $(\mathrm{N}, \mathrm{P}, \mathrm{K}$ dan $\mathrm{Ca}$ ) yang dibutuhkan selada juga semakin baik. Unsur $\mathrm{N}$ (nitrogen) merupakan unsur penbentuk struktur asam nukleat pada tanaman, asam nukleat sendiri adalah bagian pertama untuk sintesis protein, dan protein sendiri adalah penyusun utama dari hormon, termasuk hormon yang berpengaruh terhadap penambahan tinggi tanaman.

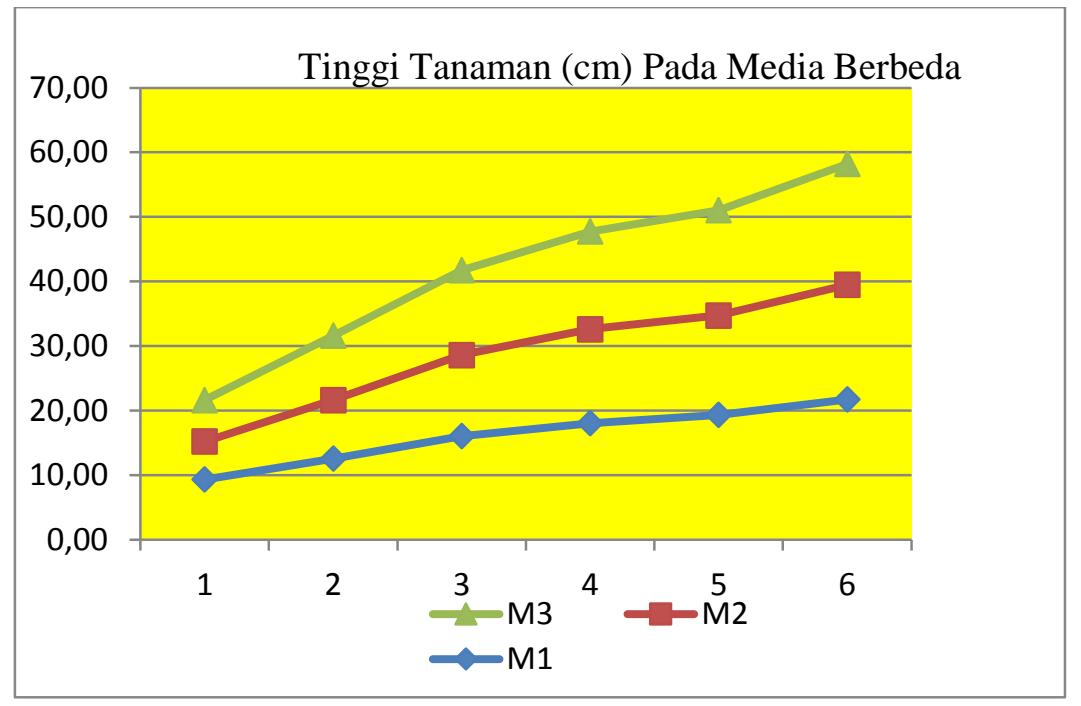

Gambar 1. Grafik tinggi tanaman dengan proporsi abu sekam, M1 (3:1), M2 (2:2) dan M3 (1:3), pada pengamatan hari pertama hingga keenam.

Variabel yang selanjutnya diamati adalah berat kering akar dan berat kering tajuk yang diukur pada hari keenam ketika panen. Hasil berat kering akar dan berat kering tajuk disampaiakan pada tabel 1 .

Tabel 1. Perbandingan berat kering akar dan berat kering tajuk pada tanaman selada.

Pengamatan Panen

\section{Perlakuan Bobot Kering Tajuk Bobot Kering Akar}

(gram/tanaman)

\begin{tabular}{ccccc}
\hline \multicolumn{2}{c}{ Komposisi Media Tanam $(M)$} & & & \\
M2 & 7,87 & $a$ & 0,61 & $a$ \\
M3 & 9,27 & $b$ & 0,82 & $b$ \\
M1 & 9,09 & $a b$ & 0,89 & $b$ \\
\hline
\end{tabular}

Interaksi antara arang atau abu sekam dengan proporsi penambahannya dapat meningkatkan panjang akar lateral, tetapi tidak dapat meningkatkan berat 
Tri Kurniastuti, Palupi Puspitorini, Tyas Nyonita Punjungsari, 2017. Pengaruh Penambahan Abu sekam Padi (Rice Husk Ash) dengan Proporsi Berbeda Terhadap Pertumbuhan Selada Air (Lactuca sativa L.). Journal Viabel Pertanian. (2017),11(2) 1-8

kering tajuk dan berat kering akar. Faktor yang berpengaruh terhadap pertumbuhan akar adalah adanya ruang pori-pori tanah. Pori-pori tanah adalah ruang yang dapat ditembus oleh akar dan berisi udara untuk respirasi akar. Akar lateral meningkat panjangnya disebabkan oleh celah-celah yang terbentuk karena penambahan pembenah tanah dengan berbagai proporsi penambahannya. Celah-celah ini menyebabkan adanya ruang yang dapat ditembus oleh akar lateral. Menurut Hasanah (2009), pertumbuhan akar terjadi dengan cara akar masuk ke dalam poripori makro yang ukurannya lebih besar dari pada diameter akar atau yang diameternya sama besar dengan diameter akar.

Penambahan arang ataupun abu sekam dengan berbagai proporsi tidak dapat meningkatkan berat kering akar maupun berat kering tajuk. Hal tersebut dikarenakan arang ataupun abu sekam yang ditambahkan dalam jumlah banyak ataupun sedikit sulit terdekomposisi. sehingga penambahan arang ataupun abu sekam dalam jumlah banyak ataupun sedikit tidak efektif untuk meningkatkan berat kering akar dan tajuk. Hal tersebut sesuai dengan penelitian Yulfianti (2011), bahwa penambahan abu sekam pada berbagai takaran tidak menunjukkan pengaruh terhadap pertumbuhan tanaman, tetapi lebih berpengaruh terhadap produksi tanaman. Penambahan pembenah tanah, arang ataupun abu sekam dapat meningkatkan panjang akar lateral dan berat kering tajuk, tetapi tidak dapat meningkatkan berat kering akar.

Penambahan pembenah tanah dapat menyebabkan terbentuknya celah-celah yang mudah ditembus akar untuk tumbuh. Celah-celah tersebut terbentuk secara mekanis. Penambahan arang sekam menyebabkan akar lateral tumbuh lebih panjang dibandingkan dengan abu sekam. Arang sekam mempunyai ukuran partikel lebih besar, sehingga antar partikelnya memiliki celah yang lebih besar dari pada abu sekam yang ukurannya sangat kecil. Ukuran partikel yang sangat kecil pada abu sekam menyebabkan akar lebih sulit untuk tumbuh. Dalam penelitiannya Supriyanto (2010), menjelaskan bahwa penambahan arang sekam dapat meningkatkan panjang akar, hal ini dikarenakan pada media yang ditambahkan abu sekam menghasilkan berat kering tajuk yang lebih tinggi dari pada arang sekam. Penambahan arang atau abu sekam menyebabkan adanya ruang yang dapat ditembus akar, sehingga akar dapat menyerap hara dalam jumlah banyak. Abu sekam mengandung $\mathrm{SiO} 2, \mathrm{P}$ dan $\mathrm{K}$ yang berasal dari proses pengabuan melalui pembakaran pada suhu tinggi, sehingga penambahan abu sekam dapat meningkatkan $\mathrm{P}$ dan $\mathrm{K}$ tanah liat.

Menurut Paiman (1999), bahwa penambahan abu sekam dapat meningkatkan kadar $\mathrm{P}$ tanah dan $\mathrm{K}$ total tanah. $\mathrm{P}$ dan $\mathrm{K}$ merupakan makronutrien yang penting untuk tanaman. Oleh karena itu, penambahan abu sekam dapat meningkatkan unsur hara di sekitar akar dibandingkan dengan arang sekam yang sedikit mengandung hara. Penambahan pembenah tanah tidak dapat meningkatkan berat kering akar. Hal tersebut dikarenakan penambahan arang atau abu sekam tidak dapat meningkatkan aerasi tanah, sehingga respirasi akar rendah. Aerasi tanah yang kurang optimal 
Tri Kurniastuti, Palupi Puspitorini, Tyas Nyonita Punjungsari, 2017. Pengaruh Penambahan Abu sekam Padi (Rice Husk Ash) dengan Proporsi Berbeda Terhadap Pertumbuhan Selada Air (Lactuca sativa L.). Journal Viabel Pertanian. (2017),11(2) 1-8

dibuktikan dengan porositas tanah yang rendah. Menurut Sitompul dan Guritno (1995), bahwa respirasi berperan untuk proses pertumbuhan, yaitu pembentukan biomassa

\section{KESIMPULAN}

Proporsi terbaik untuk meningkatkan pertumbuhan selada adalah M3 (1:3) dimana jumlah abu sekam lebih banyak dari pada tanah atas. Penambahan abu sekam memberikan efek positif terhadap produksi selada Lactuca sativa L namun kurang memberikan pengaruh terhadap pertumbuhannya karena abu sekam tidak dapat meningkatkan aerasi tanah, sehingga respirasi akar rendah. Aerasi tanah yang kurang optimal dibuktikan dengan porositas tanah yang rendah. Respirasi berperan untuk proses pertumbuhan, yaitu pembentukan biomassa.

\section{DAFTAR PUSTAKA}

Agustina, L., 2004. Dasar-Dasar Nutrisi Tanaman. Rineka Cipta, Jakarta.

Azis, A.H., M.Y. Surung., dan Buraerah., 2006. Produktivitas Tanaman Selada pada Berbagai Dosis Posidan-HT. Jurnal Agrisistem. 2, 36-42.

Hanafiah, K.A. 2005. Dasar-dasar Ilmu Tanah. Raja Grafindo Persada, Jakarta

Hasanah, U. 2009. Respon Tanaman Tomat (Lycopersicum esculentum Mill) pada Awal Pertumbuhan terhadap Ukuran Agregat Tanah Entisol. Jurnal Agroland 16(2): 103-109.

Indranada, H.K. 1989. Pengelolaan Kesuburan Tanah. Bina Aksara, Jakarta.

Kiswando, S. 2011. Penggunaan Abu Sekam dan Pupuk ZA terhadap Pertumbuhan dan Hasil Tomat (Lycopersicum esculentum Mill). Embryo 8(1):9-17.

Nazaruddin., 2003. Budidaya dan Pengaturan Panen Sayuran Dataran Rendah. Penebar Swadaya, Jakarta.

Setyorini dkk. 2003. Penelitian Peningkatan Produktivitas Lahan melalui Teknologi Pertanian Organik. Laporan Bagian Proyek Penelitian Sumberdaya Tanah dan Pengkajian Teknologi Pertanian partisipatif

Sitompul, S.M. dan Bambang Guritno. 1995. Analisis Pertumbuhan Tanaman. Gajah Mada University press..Yogyakarta.

Supriyanto dan Fiona Fidryaningsih. 2010. Pemanfaatan Arang Sekam untuk Memperbaiki Semai Jabon (Anthocephalus cadamba (Roxb) Miq) pada Media Subsoil. Jurnal Silvikultur Tropika 1(1):24-28

Syahruddin. 1999. Pemberian Pupuk Arsyad. 2000. Konservasi Tanah dan Air. Institut Pertanian Bogor Press, Bogor. 